\title{
PERANCANGAN APLIKASI PENGOLAHAN DATA JURU PARKIR PADA DINAS PERHUBUNGAN KOTA METRO
}

\author{
Nadia Fitriani ${ }^{(1)}$ Sudarmaji ${ }^{(2)}$ \\ Jurusan Ilmu Komputer, Fakultas Ilmu Komputer,Universitas Muhammadiyah Metro \\ Jl.Gatot Subroto No.100 Yosodadi Kota Metro, Telpon :(0725)42445-Fax(0725)42454 \\ E-mail: Majidarma5022@gmail.com
}

\begin{abstract}
Abstrak
Tugas akhir ini merupakan hasil dari analisis dan observasi yang penulis lakukan terhadap sistem informasi yang sedang berjalan dan hasil perancangan yang baru dari aplikasi pengolahan data juru parkir pada Dinas Perhubungan Kota Metro. Pada saat ini pengolahan data juru parkir sudah terkomputerisasi, namun pada kenyataannya masih ditemui beberapa permasalahan yaitu: a) tidak terkendalinya dan tidak optimalnya pengolahan data juru parkir, b) dalam pencarian data karyawan masih kurang efektif, c) pembuatan laporan terkadang masih terjadi kesalahan. Adapun tujuan penelitiannya adalah sebagai berikut: untuk merancang aplikasi data juru parkir pada Dinas Perhubungan Kota Metro dan untuk memberikan kemudahan dalam proses pencarian data juru parkir dan proses cetak laporan pada setiap akhir bulan pada Dinas Perhubungan Kota Metro. Penelitian ini menggunakan beberapa metode berupa pengamatan, wawancara, dokumentasi dan studi pustaka. Selain itu dalam perkembangan aplikasi penulis menggunakan aliran informasi, diagram konteks, data flow diagram, dan entity relathionship diagram. Software pendukung dalam pembuatan aplikasi ini adalah Delphi 7, database MySQL dan Quick Report. Kegunaan Penelitian yaitu ntuk meningkatkan kinerja pegawai pada bagian UPT Perparkiran Dinas Perhubungan Kota Metro dalam pendataan juru parkir, untuk mempermudah proses pencarian data juru parkir pada Dinas Perhubungan Kota Metro, untuk mempermudah laporan data juru parkir dan meningkatkan perkembangan kinerja sistem dari yang lama ke sistem yang baru pada Dinas Perhubungan Kota Metro.

Kunci : PERANCANGAN APLIKASI PENGOLAHAN DATA JURU PARKIR, BORLAND DELPHI 7.0, MYSQL, QUICK REPORT.

\section{PENDAHULUAN}

Dinas Perhubungan Kota Metro adalah instansi yang dibentuk berdasarkan UndangUndang Nomor 12 Tahun 1999, Kota Metro menjadi salah satu Daerah Otonom baru di Provinsi Lampung yang berwenang

menyelenggarakan Pemerintahan dan Pembangunan tersebut maka dibentuk Dinas Instansi untuk membantu pelaksanaannya sesuai dengan bidang masing-masing Dinas Perhubungan Kota Metro dibentuk berdasarkan Peraturan Daerah Kota Metro
\end{abstract}


Nomor 12 Tahun 2010 Perubahan atas Peraturan Daerah Kota Metro Nomor 07 Tahun 2008 tentang pembentukan organisasi dan tata kerja perangkat daerah Kota Metro. Hakekat membentuk Dinas Perhubungan untuk memperbesar peranan pemerintahan daerah sebagai penyelenggara pemerintahan pembangunan yang penyerahan sebagian urusannya diserahkan kepada Daerah TK.I dan Daerah TK.II serta tugas perbantuan oleh pemerintah TK.I. Dijelaskan dalam Firman Allah QS. An-Nahl ayat 8 tentang kendaraan:

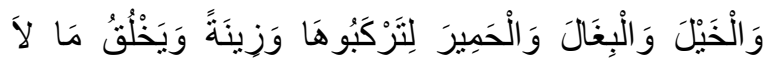
نَعَلَكُونَنَ

"Dan (Dia telah Menciptakan) kuda, bagal dan keledai, untuk kamu tunggangi dan (menjadi) hiasan. Allah Menciptakan apa yang tidak kamu ketahui”.

Kondisi saat ini pada pengolahan data juru parkir Dinas Perhubungan Kota Metro masih mengalami kesulitan yaitu dalam hal pengolahan data juru parkir yang masih menggunakan buku besar dan banyaknya jumlah juru parkir yang mencapai 90 orang lebih sehingga hal ini mengakibatkan sering terjadinya kesalahan dalam proses pencatatan data juru parkir, pencarian data juru parkir yang kurang efektif karena harus mencari satu persatu data juru parkir pada buku besar. Kemudian belum adanya aplikasi yang digunakan oleh petugas sehingga proses pembuatan laporan data juru parkir perbulan masih menggunakan Microsoft Excel, hal tersebut mengakibatkan memakan waktu yang lama dan sering mengalami keterlambatan. Berdasarkan latar belakang diatas maka penulis akan mengambil judul "PERANCANGAN APLIKASI PENGOLAHAN DATA JURU PARKIR PADA DINAS PERHUBUNGAN KOTA METRO".

\section{KAJIAN PUSTAKA DAN LANDASAN TEORI}

Menurut Kamus Besar Bahasa Indonesia yang dikutip oleh Neyfa dan Tamara (2016:85) menyimpulkan bahwa: "Aplikasi adalah suatu program komputer yang dibuat untuk mengerjakan dan melaksanakan tugas khusus dari pengguna".

Berdasarkan definisi diatas dapat disimpulkan bahwa "Aplikasi adalah software yang dibuat untuk melakukan proses perintah yang diperlukan untuk melaksanakan tugas-tugas dengan tujuan tertentu".

\subsection{Definisi Data}

Menurut Wilkinson yang dikutip oleh Kadir (2009:3 ) menyatakan bahwa: "Data yaitu berisi fakta, angka, bahkan simbol mentah. Secara bersama-sama merupakan masukan bagi suatu sistem informasi".

Menurut Kadir (2009:3) menyatakan bahwa "Data adalah Deskripsi tentang benda, kejadian, aktivitas dan transaksi yang tidak mempunyai makna atau tidak berpengaruh secara langsung kepada pemakai".

Berdasarkan pengertian Data diatas dapat diambil suatu kesimpulan bahwa data adalah 
"Suatu bahan mentah yang kelak dapat diolah lanjut untuk menjadi sesuatu yang lebih bermakna".

\subsection{Definisi Pengolahan Data}

Menurut Hartono (1999:2) menjelaskan bahwa: "Pengolahan Data (data processing) adalah manipulasi dari data kedalam bentuk yang lebih berguna dan lebih berarti, yang berupa suatu informasi. Menurut Kristanto yang dikutip oleh Purba (2016:25) menyatakan bahwa: "Pengolahan Data adalah waktu yang digunakan menggambarkan perubahan bentuk data menjadi informasi yang memiliki kegunaan".

Berdasarkan pengertian diatas dapat disimpulkan bahwa pengolahan data adalah "Suatu data yang dibentuk menjadi informasi yang lebih berguna".

\subsection{Definisi Juru Parkir}

Menurut Kamus Besar Bahasa Indonesia (KBBI) yang disusun oleh Tim Penyusun kamus Pembinaan dan Pengembangan Bahasa Diterangkan bahwa Juru Parkir merupakan orang yang pekerjaannya mengatur perparkiran kendaraan.

\subsection{Perlengkapan Juru Parkir}

Peluit

Pakaian seragam

Karcis

Rambu kecil stopyang dipasang pada satu tongkat dengan lampu berwarna merah bila petugas pada malam hari

Rompi yang memantulkan sinar (scothlite) pada saat hari gelap atau malam hari.

\subsection{Tugas Juru Parkir}

Memberikan pelayanan kepada semua kendaraan yang masuk dan keluar di tempat parkir

Menyerahkan atau menempalkan karcis parkir kendaraan dan menerima pembayaran retribusi sesuaitarif tertentu di dalamnya Menjaga ketertiban, keindahan, kebersihan dan membantu keamanan terhadap kendaraan yang di parkir
Apabila cuaca panas terik tukang parkir harus menyediakan sesuatu untuk menutupi panas tempat duduk pada kendaraan sepeda motor pada kendaraan sepeda motor

Mengeluarkan kendaraan dengan aman dan lancar.

\subsection{Tanggung Jawab Juru Parkir}

Pengelola parkir bertanggung jawab atas motor dan segala benda yang "menempel" pada motor karena berdasarkan Pasal 57 UU No. 22 Tahun 2009 tentang Lalu Lintas dan Angkutan Jalan, setiap kendaraan bermotor yang dioperasikan di jalan wajib di lengkapi helm. Dengan begitu helm dan motor dianggap satu kesatuan. Konsekuensinya, pengelola tempat parkir tidak saja harus menjaga motor. Tetapi juga harus menjaga helm sebagai satu kesatuan dengan motor, begitupun dalam hal helm hilang dari tempat penitipan yang ada ditempat parkir tersebut, maka pengelola parkir juga bertanggung jawab sebagaimana dijelaskan di atas mengenai penitipan.

\subsection{Definisi Borland Delphi 7}

Menurut Irnawan (2006:1) menyatakan bahwa: "Delphi adalah suatu bahasa pemrograman (development language) yang digunakan untuk merancang suatu aplikasi program".

Delphi yang pertama dirilis adalah Delphi 1 (1995), untuk windows 3.1 (16 bit). Setahun kemudian Delphi mengeluarkan Delphi 2 versi 32 bit yang kompatibel dengan windows 95. Kemudian secara periodik setiap tahun Delphi mengeluarkan versi terbaru, sampai sekarang sudah keluar dengan versi terbarunya yaitu Delphi versi 2010. Berikut tampilan logo Delphi 7. Terdapat pada Gambar 2.1 


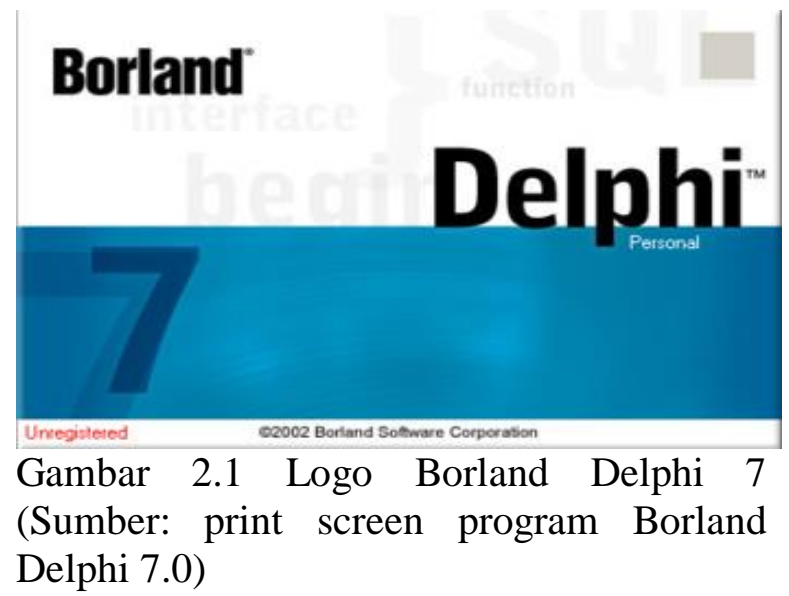

\subsection{Komponen/IDE Dalam Delphi}

Jendela IDE Delphi 7 mempunyai perangkat-perangkat yang dapat dipergunakan untuk memudahkan seorang programmer dalam membuat program.

\subsection{GUI Builder}

GUI Builder merupakan jendela utama yang didalamnya terdapat komponen untuk merancang GUI. Terdapat pada Gambar 2.2

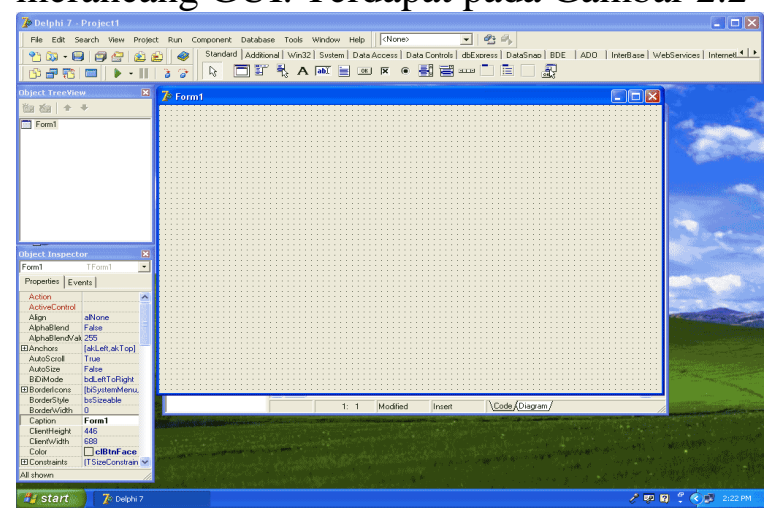

Gambar 2.2 GUI Builder (Sumber: print screen program Borland Delphi 7.0)

\subsection{Object Tree View}

Merupakan sebuah diagram pohon yang menggambarkan hubungan logis, menghubungkan semua komponenyang terdapat dalam suatu proyek program. Komponen tersebut meliputi form, modul atau frame. Fungsinya digunakan untuk menampilkan seluruh daftar komponen program dalam sebuah aplikasi program sesuai dengan penempatannya.Terdapat pada Gambar 2.3

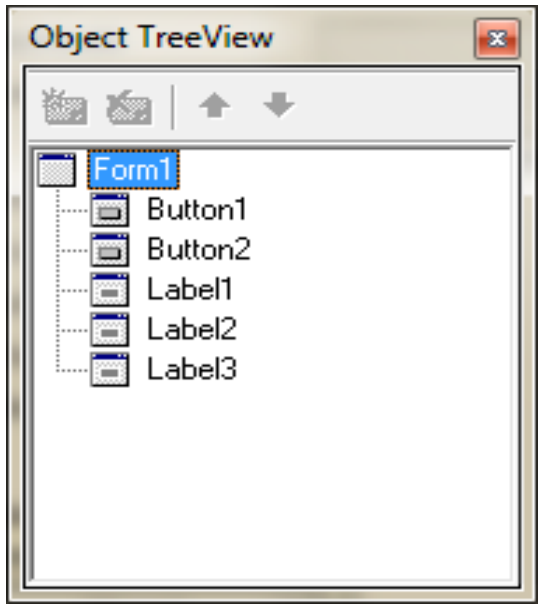

Gambar 2.3 Jendela Object Tree View (Sumber print screen program Borland Delphi 7.0)

\subsection{Object Inspector}

Merupakan jendela yang digunakan untuk mengatur tampilan komponen pada form, misal bagaimana mengubah tulisan button pada command button menjadi simpan atau menghapus tulisan pada label dan mengganti nama menjadi Nama Mahasiswa atau memberikan perintah tertentu pada sebuah komponen sehingga ada interaksi ketika program dijalankan.

Secara umum Object Inspector terbagi menjadi 2 yaitu :

\subsection{Properties}

Digunakan untuk mengatur tampilan pada sebuah komponen baik itu meliputi penggantian nama, warna, jenis huruf, border dan lain-lain. Gambar jendela Inspector(properties) terdapat pada Gambar 2.4 


\begin{tabular}{|c|c|c|}
\hline Object Inspect & & 8 \\
\hline Form1 & TForm1 & - \\
\hline Properties E & ents| & \\
\hline AutoScroll & True & A \\
\hline AutoSize & False & \\
\hline BiDiMode & bdleftToRight & $\equiv$ \\
\hline ĐBordelcons & [biSystemMenu,biMinin & \\
\hline BorderStyle & bssizeable & \\
\hline Borderwidth & 0 & \\
\hline Caption & Form1 & \\
\hline ClientHeight & 442 & \\
\hline Clientwidth & 912 & \\
\hline Color & $\square$ clBtnFace & 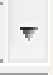 \\
\hline All shown & & 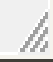 \\
\hline
\end{tabular}

Gambar 2.4 Jendela Inspector (Properties) (Sumber: print screen program Borland Delphi 7.0)

\subsection{Events}

Merupakan jendela properties yang digunakan untuk memberikan fungsi yang lebih detail dari fungsi sebenarnya. Misalnya ketika tombol simpan di klik maka program akan menjalankan perintah penyimpanan data. Dari kalimat tersebut ada event click untuk mengeksekusi sebuah tombol Simpan. Perintah event click tersebut dapat diberikan melalui jendela events. Terdapat pada Gambar 2.5

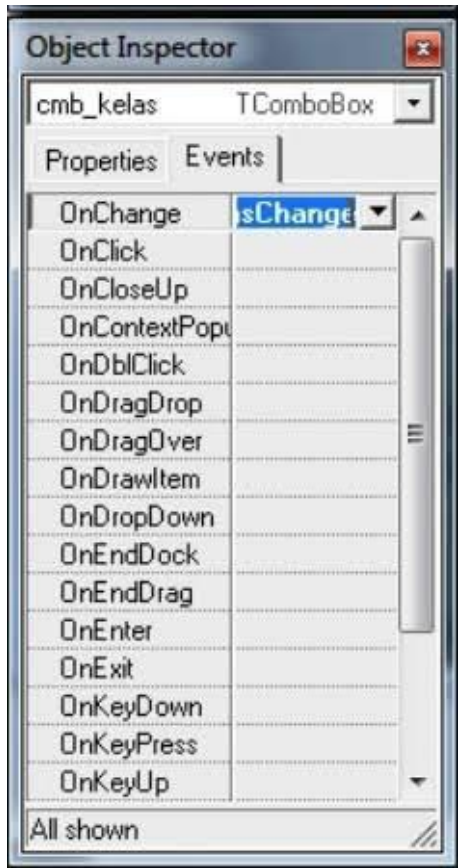

Gambar 2.5 Jendela Events pada Object Inspector (Sumber: print screen program Borland Delphi 7.0)

\subsection{Form Designer}

Merupakan tempat yang digunakan untuk merancang semua aplikasi program yang diambil dari komponen pallete. Terdapat pada Gambar 2.6

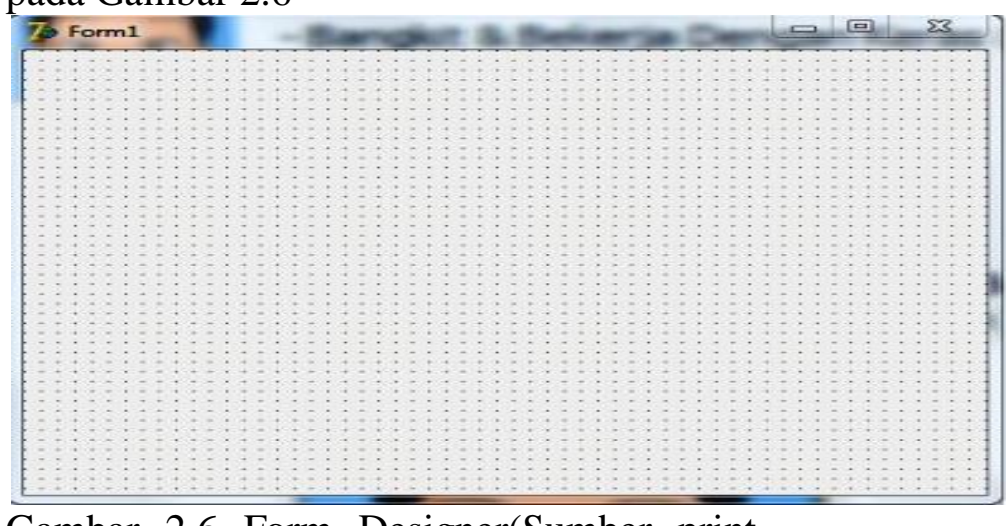

Gambar 2.6 Form Designer(Sumber print screen program Borland Delphi 7.0)

\subsection{Component Pallete}

Merupakan kumpulan icon yang digunakan untuk merancang suatu aplikasi untuk membentuk sebuah aplikasi yang user interface. Component Pallete berisi kumpulan icon yang melambangkan komponen-komponen pada Visual 
Component Library (VCL). VCL adalah pustaka komponen yang dengannya dapat membangun sebuah aplikasi. Pada Component Pallete terdapat beberapa tab, yaitu Standard, Additionals, Data Access, Data Controls, dbExpress, Data Snap, dan $B D E$. Terdapat pula 17 icon yang memiliki fungsi masing-masing untuk membangun suatu program. Diantara icon tersebut adalah Pointer, Frames, Main Мenu, Рор Up Menu, Label, Edit, Memo, Button, Check Box, Radio Button, List Box, Combo Box, Scroll Bar, Grop Box, Radio Group, Panel dan Action List. Dalam komponen pallete semua icon dikelompokkan dalam berbagai komponen sesuai dengan fungsi dan kegunaannya.

Tampilan Pallete windows. Terdapat pada Gambar 2.7

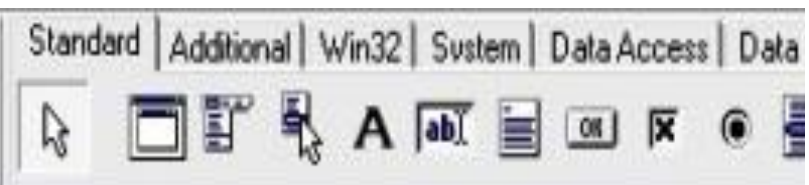

Gambar 2.7 Komponen Pallet (Sumber print screen program Borland Delphi 7.0)

Tabel 2.1 Fungsi Tools Pallete Windows

\begin{tabular}{|c|c|c|c|}
\hline No & Icon & Name & Fungsi \\
\hline 1 & s & Pointer & $\begin{array}{l}\text { Mengembalikan fungsi mouse } \\
\text { ke defaultnya }\end{array}$ \\
\hline 2 & $\square$ & Frame & $\begin{array}{l}\text { Membentuk suatu frame } \\
\text { terhadap obyek yang ada } \\
\text { didalamnya }\end{array}$ \\
\hline 3 & 㖘 & Main menu & Membuat menu Utama \\
\hline 4 & 完 & Popup Menus & \\
\hline 5 & A & label & Hanya untuk menampilkan Teks \\
\hline 6 & $\overline{\mathrm{abI}}$ & Edit & $\begin{array}{l}\text { Untuk menampilkan dan input } \\
\text { data (1 baris) }\end{array}$ \\
\hline 7 & 圁 & Memo & $\begin{array}{l}\text { Sama seperti edit tetapi } \\
\text { mempunyai kapasitas lebih } \\
\text { besar (lebih dari } 1 \text { baris) }\end{array}$ \\
\hline 8 & 애 & Button & $\begin{array}{l}\text { Digunakan untuk melakukan } \\
\text { eksekusi terhadap suatu proses }\end{array}$ \\
\hline 9 & 区 & Checkbox & $\begin{array}{l}\text { Digunakan untuk menentukan } \\
\text { pilihan lebih dari satu }\end{array}$ \\
\hline 10 & (o & Radio Button & $\begin{array}{c}\text { Digunakan untuk menentukan } \\
\text { pilhan, tetapi hanya satu pilhan } \\
\text { yang bisa digunakan }\end{array}$ \\
\hline 11 & 钽盟 & List Box & $\begin{array}{l}\text { Menmpilkan pilihan dalam } \\
\text { bentuk list }\end{array}$ \\
\hline 12 & 圄 & Combo Box & $\begin{array}{l}\text { Menampilkan pilihan dalam } \\
\text { bentuk popup }\end{array}$ \\
\hline 13 & Im & Scroll Bar & $\begin{array}{l}\text { Merupakan icon yang berupa } \\
\text { baris status }\end{array}$ \\
\hline 14 & $\square$ & Group Box & $\begin{array}{c}\text { Digunakan untuk } \\
\text { mengelompokan suatu icon }\end{array}$ \\
\hline 15 & 亘 & Radio Group & $\begin{array}{l}\text { Digunakan untuk } \\
\text { mengelompokan pilihan }\end{array}$ \\
\hline
\end{tabular}

2.16 Code Editor
Bagian dari delphi yang digunakan untuk menuliskan kode program. Pada bagian code editor terdapat bagian utama yaitu bagian paling kiri yang berupa angka menunjukkan baris dan kolom. Keterangan modefied menunjukkan bahwa telah terjadi modifikasi terhadap baris program. Dan paling kanan menunjukkan status keyboard tentang tombol insert atau over white. Terdapat pada Gambar 2.8

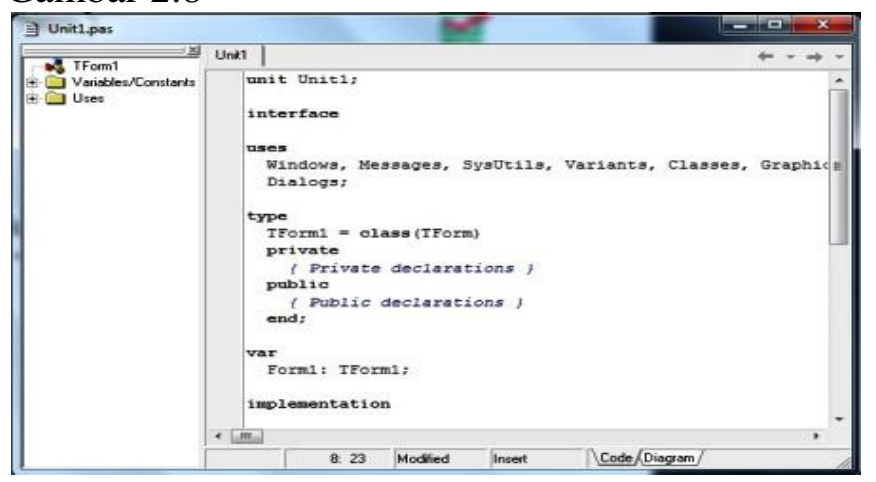

Gambar 2.8 Code Editor (Sumber print screen program Borland Delphi 7.0)

\subsection{Definisi Basis Data}

Berikut ini merupakan penjelasan dari beberapa ahli tentang penjelasan basis data yaitu:

Menurut Sutanta yang dikutip oleh Sembiring dan Nurhayati (2012:14) mendefinisikan bahwa: "Basis Data adalah suatu kumpulan data terhubung (interrelated data) yang disimpan secara bersama-sama pada suatu media". Menurut Widianti yang dikutip oleh Sofyan, dkk (2015:39) menyatakan bahwa basis data merupakan: Suatu kumpulan data terhubung yang disimpan secara bersama-sama pada suatu media, tanpa adanya suatu kerangkapan data, sehingga mudah untuk digunakan kembali, dapat digunakan oleh satu atau lebih program aplikasi secara optimal, data disimpan tanpa mengalami ketergantungan pada program yang akan menggunakannya, data disimpan sedemikian rupa sehingga apabila ada penambahan, pengambilan dan modifikasi data dapat dilakukan dengan mudah dan terkontrol. Dari definisi diatas 
dapat disimpulkan bahwa basis data adalah kumpulan informasi atau data yang disusun secara terhubung yang disimpan secara bersama-sama pada suatu media sehingga mudah untuk digunakan kembali.

\section{METODE}

Metode adalah prosedur, konsep-konsep, pekerjaan, atau aturan yang digunakan oleh suatu ilmu pengetahuan, memperoleh data guna menyusun Tugas Akhir, penulis menggunakan metode-metode yaitu sebagai berikut:

3.1 Studi Lapangan

Studi lapangan adalah metode pengumpulan data yang secara langsung ke objek dan pengumpulan datanya menggunakan teknikteknik sebagai berikut:

3.2 Pengamatan(Observasi)

Yaitu melakukan penelitian secara langsung pada Dinas Perhubungan Kota Metro, sehingga penulis dapat mengetahui data secara langsung.

3.3 Wawancara

Dilakukan melalui pengumpulan data dengan cara tanya jawab secara langsung kepada HENDI NUGROHO, S.H selaku kepala UPT Perparkiran pada Dinas Perhubungan Kota Metro.(Terlampir Data Tabel Wawancara).

\subsection{Dokumentasi}

Dokumentasi yaitu penelitian yang dilakukan dengan cara mengumpulkan dokumen-dokumen yang ada pada Dinas Perhubungan Kota Metro untuk kelengkapan pengumpulan data.

\section{HASIL DAN PEMBAHASAN}

Berikut ini gambaran umum sistem yang diusulkan, gambar 4.1 Gambaran Umum Sistem Yang Diusulkan.

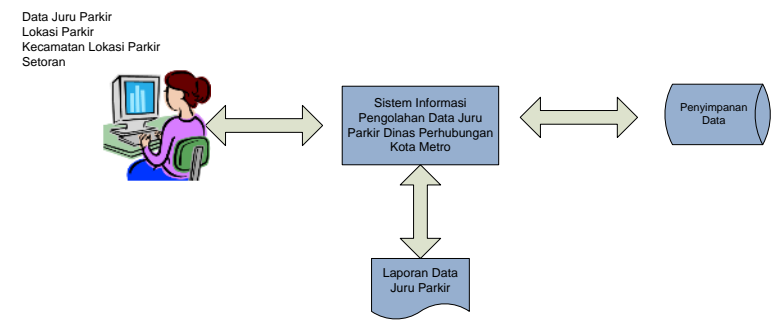

Gambar 4.1 Gambaran Umum Sistem Yang

Diusulkan

Sistem yang di usulkan memiliki beberapa keunggulan dari sistem yang sedang berjalan. Pengolahan data juru parkir pada Dinas Perhubungan Kota Metro ini dapat memfilter data sehingga mengatasi permasalahan yang sering terjadi dalam kesamaan data saat penginputan, serta pencarian data dan pembuatan rekap laporan lebih memudahkan unit kerja UPT Perparkiran.

4.1 Tujuan Perancangan Sistem

Tujuan perancangan sistem ini adalah untuk merancang aplikasi pengolahan data juru parkir pada Dinas Perhubungan Kota Metro. Untuk memberikan kemudahan dalam proses pencarian data juru parkir, dan proses cetak laporan pada setiap akhir bulan pada Dinas Perhubungan Kota Metro.

4.2 Kegunaan Perancangan Sistem

Untuk meningkatkan kinerja pada pegawai UPT Perparkiran pada Dinas Perhubungan Kota Metro. Untuk mempermudah proses pencarian data juru parkir pada Dinas Perhubungan Kota Metro. Untuk mempermudah laporan data juru parkir pada Dinas Perhubungan Kota Metro. Selain bagi instansi kegunaannya bagi prodi yaitu menambah referensi hasil penelitian untuk perkembangan dan penelitian selanjutnya, sebagai bahan masukan untuk memperbaiki 
Vol. 01, No. 02, Oktober 2020

praktik-praktik pembelajaran agar dosen menjadi lebih kreatif, efektif dan efisien sehingga kualitas pembelajaran dan hasil belajar Mahasiswa meningkat. Dan bagi penulis kegunaannya yaitu meningkatkan hasil belajar dan solidaritas Mahasiswa untuk menemukan pengetahuan dan mengembangkan wawasan, meningkatkan kemampuan menganalisis suatu masalah melalui pembelajaran dengan model pembelajaran inovatif.

4.3 Aliran Sistem Yang Diusulkan

Aliran sistem dimulai dari petugas pendata membawa formulir pendataan juru parkir yang sudah diisi kemudian diserahkan kepada Kasubag Umum yang selanjutnya akan diinputkan lokasi parkir, kecamatan, dan data juru parkir, setelah diinput dan disimpan dalam database kemudian data siap untuk dicetaklalu hasil laporannya akan diserahkan kepada Kepala UPT Perparkiran dan akan dilakukan proses validasi, apabila disetujui laporan tersebut akan di tanda tangani, tetapi jika ada data yang salah maka akan dikembalikan ke Kasubag Umum. Setelah laporan ditanda tangani maka laporan tersebut akan dikembalikan kepada kasubag umum dan selanjutnya diarsipkan sesuai ketentuan yang ada.

\subsection{Rancangan Bagan Alir Dokumen (Flowchart) \\ Rancangan bagan alir dokumen menggambarkan arus data dan dokumn yang melalui proses terkomputerisasi. Bagan alir dokumen yang diusulkan dapat dilihat pada gambar di bawah ini.}

Tabel 4.1 Flowchart Alir Dokumen

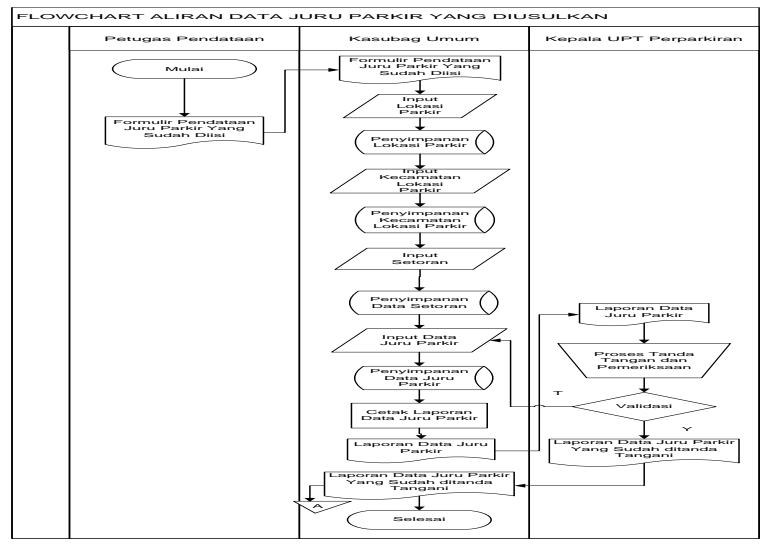

\subsection{Rancangan Diagram Contex}

Diagram ini merupakan sebuah proses yang berada di level pusat. Diagram konteks dibawah ini menggambarkan tentang prosedur aplikasi pengolahan data juru parkir pada Dinas Perhubungan Kota Metro. Dapat dilihat pada gambar 4.2

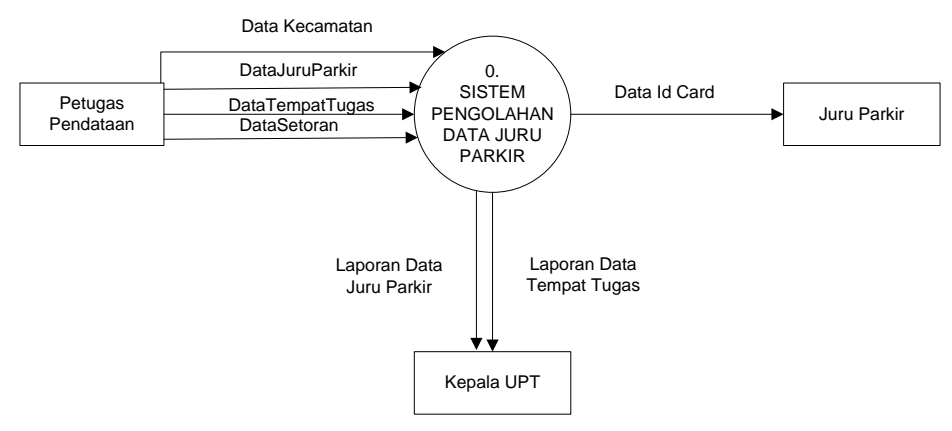

\section{Gambar 4.2 Rancangan Diagram Contex}

yang diusulkan

\subsection{Rancangan Data Flow Diagram}

Pada gambar 4.3, merupakan rancangan

Data Flow Diagram penjelasan lebih rinci dari Diagram Konteks sebelumnya. 
Vol. 01, No. 02, Oktober 2020

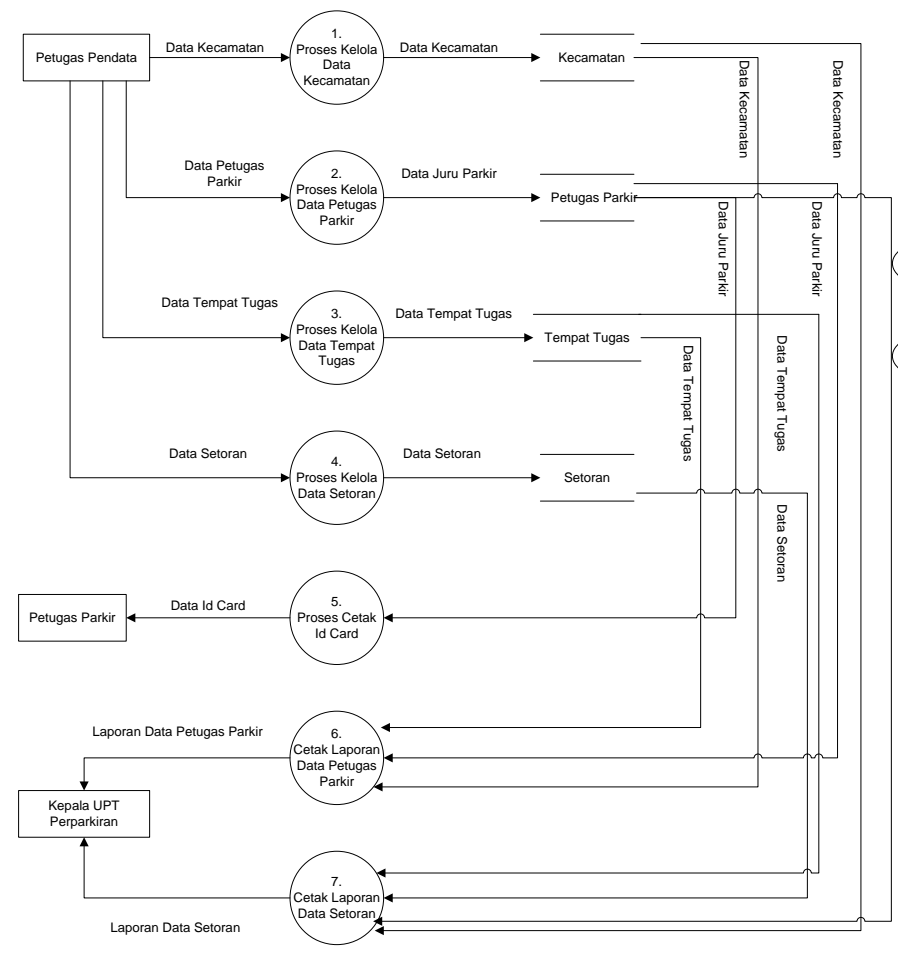

Gambar 4.3 Data Flow Diagram Level 1

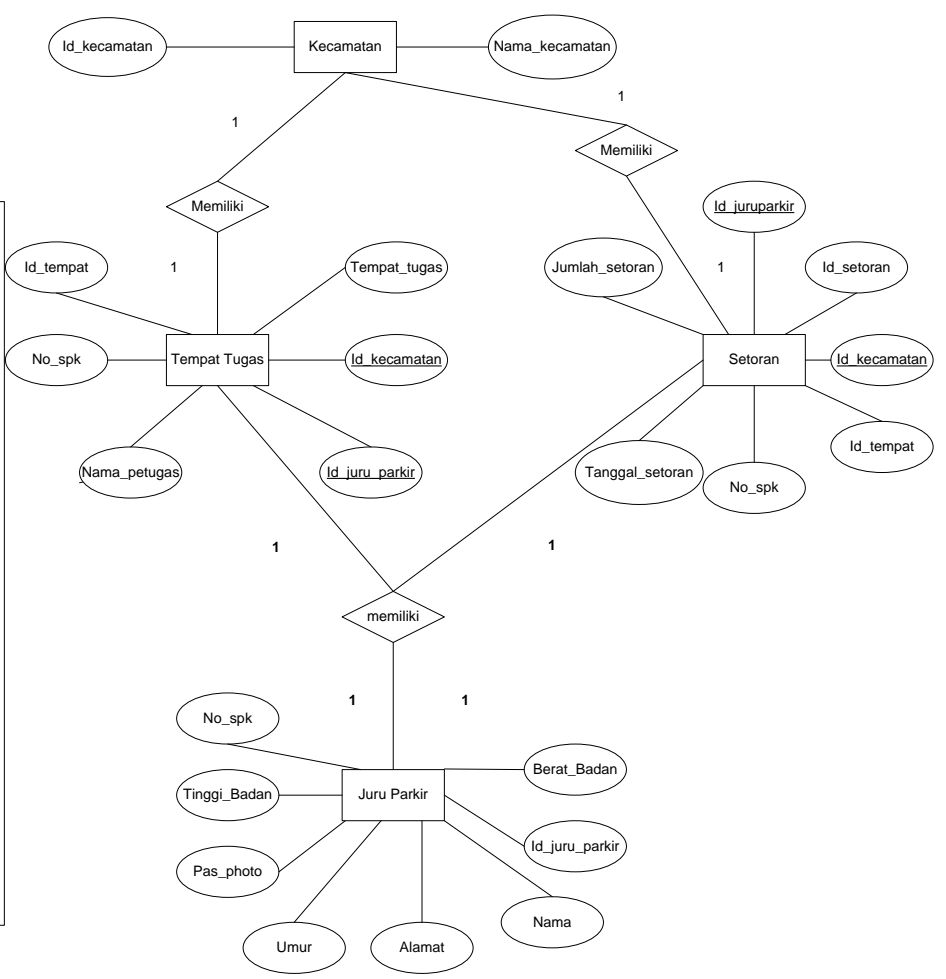

Gambar 4.4 Entity Relationship

Diagram

\subsection{Rancangan Basis Data Atau Database}

Basis data atau database adalah kumpulan file atau tabel untuk kaitannya dengan program ini. Untuk menyimpan data juru parkir pada Dinas Perhubungan Kota Metro diperlukan sebuah database.

Nama database : db_juru_parkir

Berikut adalah tabel-tabel dalam database db_juru_parkir :

Tabel Setoran

Tabel setoran digunakan untuk mengetahui setoran setiap juru parkir.

Adapun tabel setoran dapat dilihat pada Tabel 4.2:

Nama Tabel : t_setoran

Primary Key : id_setoran

Jumlah Field : 7

Tabel 4.2 Tabel Setoran 


\begin{tabular}{|c|c|c|c|}
\hline Field name & Type & Size & Keterangan \\
\hline id_setoran & Int & 11 & Primary Key \\
\hline id_juruparkir & Int & 11 & Foreign Key \\
\hline nama_petugas & Varchar & 50 & Foreign Key \\
\hline no_spk & Varchar & 50 & Nomor Spk \\
\hline tanggal_setor & Timestamp & 0 & $\begin{array}{c}\text { Tanggal } \\
\text { Setoran }\end{array}$ \\
\hline tempat_tugas & Varchar & 100 & Tempat Tugas \\
\hline id_kecamatan & Int & 11 & Foreign Key \\
\hline jumlah_setoran & Float & 0 & Jumlah \\
& & & Setoran \\
\hline
\end{tabular}

Tabel Juru Parkir

Tabel juru parkir digunakan untuk mengetahui beberapa anggota. Adapun tabel juru parkir dapat dilihat pada Tabel 4.3 :

Nama Tabel : t_juru_parkir

Primary Key : id_juru_parkir

Jumlah Field : 8

Tabel 4.3 Tabel Juru Parkir

\begin{tabular}{|c|c|c|c|}
\hline Field name & Type & Size & Keterangan \\
\hline Id_juruparkir & Int & 10 & Primary Key \\
\hline Nama & Varchar & 50 & Nama Juru Parkir \\
\hline No_spk & Varchar & 50 & Nomor SK \\
\hline Alamat_rumah & Varchar & 50 & Alamat \\
\hline Umur & Int & 11 & Umur \\
\hline Tinggi_badan & Int & 11 & Tinggi Badan \\
\hline Berat_Badan & Int & 11 & Berat Badan \\
\hline Pash_photo & Varchar & 50 & Pash Photo \\
\hline
\end{tabular}

Tabel Tempat Tugas

Tabel tempat tugas digunakan untuk mengetahui dimana titik parkir yang dimiliki oleh juru parkir. Adapun tabel lokasi parkir dapat dilihat pada Tabel 4.4 :

Nama Tabel :t_tempat_tugas

Primary Key : id_tempat

Jumlah Field : 5

Tabel 4.4 Tabel Tempat Tugas

\begin{tabular}{|l|l|l|l|}
\hline Field name & Type & Size & Keterangan \\
\hline Id_tempat & Int & 11 & Primary Key \\
\hline Tempat_tugas & Varchar & 40 & Lokasi \\
& & & Parkir \\
\hline Id_juru_parkir & Int & 11 & Foreign Key \\
\hline Id_kecamatan & Int & 11 & Foreign Key \\
\hline No_spk & Varchar & 50 & No SPK \\
\hline
\end{tabular}

Tabel Kecamatan

Tabel kecamatan digunakan untuk mengetahui dimana titik parkir pada setiap kecamatan. Adapun tabel kecamatan dapat dilihat pada Tabel 4.5 :

Nama Tabel : t_kecamatan

Primary Key :id_kecamatan

Jumlah Field : 2

Tabel 4.5 Tabel Kecamatan

\begin{tabular}{|l|l|l|l|}
\hline Field name & Type & Size & Keterangan \\
\hline Id_kecamatan & Int & 11 & Primary Key \\
\hline Nama_kecamatan & Varchar & 40 & Nama Kecamatan \\
\hline
\end{tabular}

Tabel Login

Tabel kecamatan digunakan untuk mengetahui dimana titik parkir pada setiap 
kecamatan. Adapun tabel kecamatan dapat dilihat pada Tabel 4.6 :

Nama Tabel :t_login

Jumlah Field : 2

Tabel 4.6 Tabel Login

\begin{tabular}{|l|l|l|l|}
\hline Field Name & Type & Size & Keterangan \\
\hline password & Varchar & 30 & Password \\
\hline username & Varchar & 30 & Username \\
\hline
\end{tabular}

\subsection{Relasi Tabel}

Relasi tabel digunakan untuk

menghubungkan antar tabel di database.

Adapun rancangan relasi tabel secara

keseluruhan beserta relasinya dapat dilihat pada Gambar 4.5

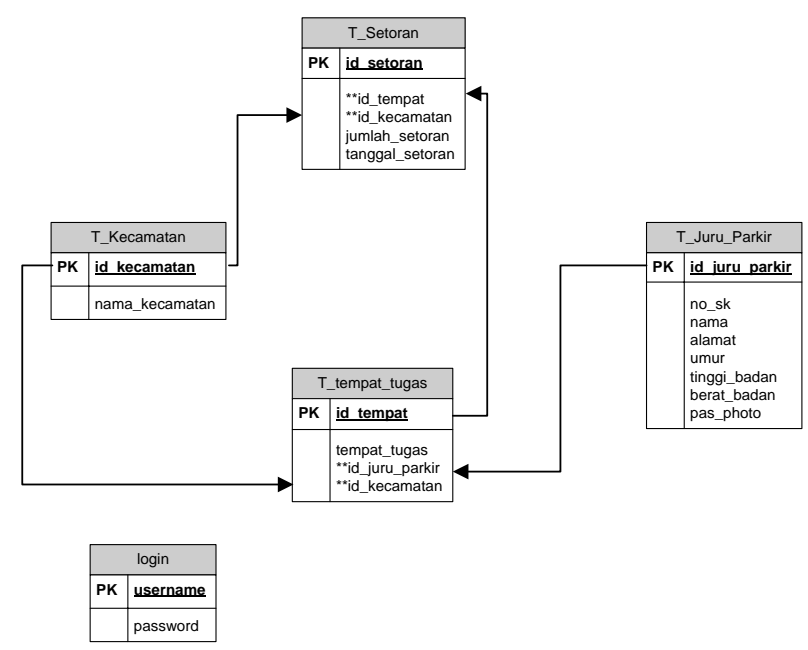

Gambar 4.5 Relasi Tabel

Keterangan :

Databasenya bernama db_juru_parkir

Tabel juru parkir berelasi dengan tabel tempat tugas

Tabel kecamatan berelasi dengan tabel setoran dan tabel tempat tugas

Kemudian tabel tempat tugas berelasi dengan tabel setoran.
PK atau (*) merupakan Primary Key

FK atau $(* *)$ merupakan Foreign Key

\subsection{Rancangan Sistem}

Sesuai dengan prosedur yang penulis rancang dan tertuang dalam aliran informasi dan diagram arus data (bagan alir dokumen), berikut ini adalah usulan dari bentuk laporan yang harus disediakan.

\subsection{Rancangan Form Menu Login}

Pada tampilan ini berfungsi untuk membuka atau masuk ke menu utama dengan user dan password yang benar. Adapun form login dapat dilihat pada Gambar 4.6

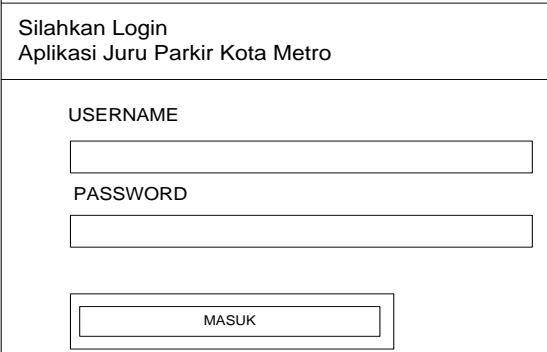

Gambar 4.6 Rancangan Form Login

Keterangan :

Username : Berisikan nama pengguna

$$
\text { Password : Berisikan password }
$$

dari pengguna

Masuk : Tombol untuk

masuk ke sistem

\subsection{Rancangan Form Menu Utama}

Tampilan ini berfungsi sebagai tempat untuk menampilkan form-form data juru parkir. Adapun rancangan form dapat dilihat pada gambar 4.7

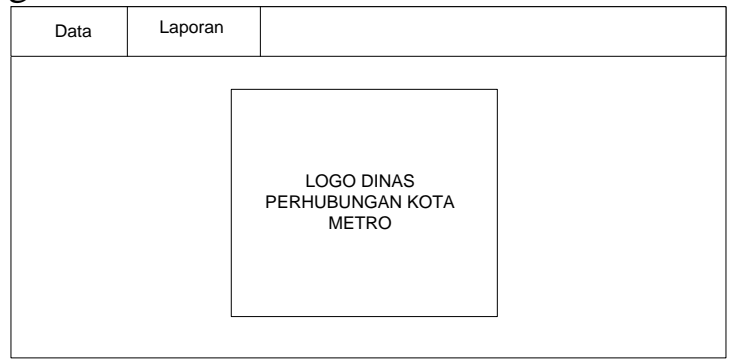


Gambar 4.7 Rancangan Form Menu Utama Keterangan :

Data : Berisikan Data dari juru parkir, tempat tugas dan setoran

Laporan : Berisikan laporan-laporan yang untuk dicetak

Logo : Berisikan identitas dari instansi tersebut.

\subsection{Rancangan Form Menu Data Juru} Parkir

Tampilan ini berfungsi sebagai tempat untuk memasukkan data juru parkir. Gambar 4.8

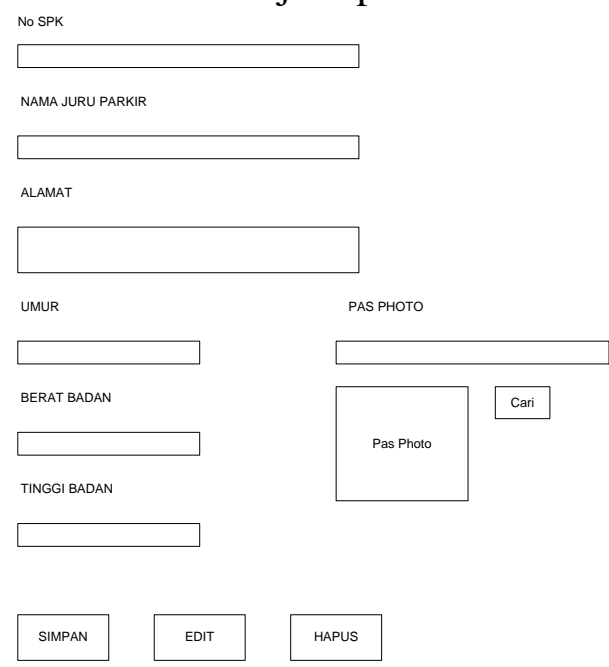

Gambar 4.8 Rancangan Form Menu Data Juru Parkir

Keterangan :

Simpan : Tombol untuk menyimpan data yang sudah diinputkan

Edit : Tombol untuk merubah data yang sudah disimpan

Hapus : Tombol untuk menghapus data yang ada.

\subsection{Rancangan Form Data Kecamatan}

Tampilan ini berfungsi untuk mengetahui dimana letak kecamatan pada tempat tugas dari juru parkir. Gambar 4.9
KECAMATAN
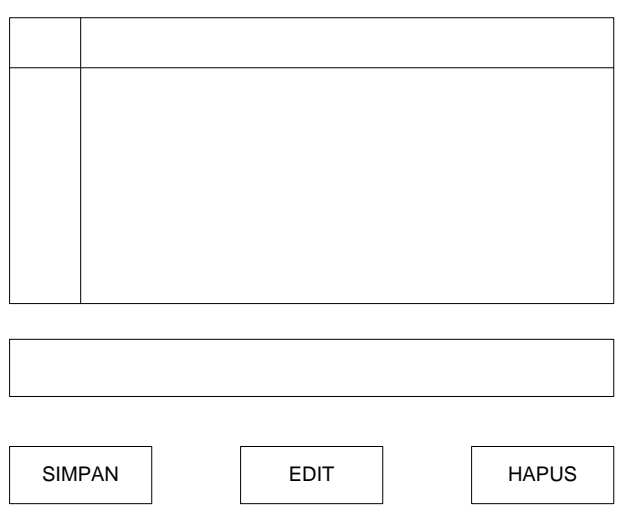

Gambar 4.9 Rancangan Form Data Kecamatan

Keterangan :

Simpan : Tombol untuk menyimpan data yang sudah diinputkan

Edit : Tombol untuk merubah data yang sudah disimpan

Hapus : Tombol untuk menghapus data yang ada.

\subsection{Rancangan Form Data Tempat Tugas}

Tampilan ini berfungsi untuk mengetahui dimana letak titik parkir pada juru setiap juru parkir. Gambar 4.10

KECAMATAN

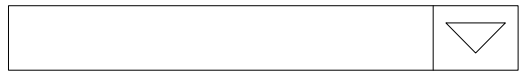

NAMA JURU PARKIR

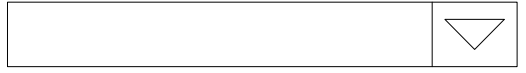

No SPK

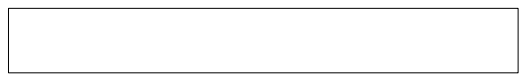

TEMPAT TUGAS
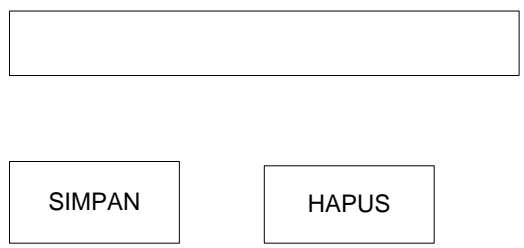
Vol. 01, No. 02, Oktober 2020

Gambar 4.10 Rancangan Form Menu Tempat Tugas

Keterangan :

Simpan : Tombol untuk menyimpan data yang sudah diinputkan

Hapus : Tombol untuk menghapus data yang ada.

Combobox 1 : Tombol untuk memilih kecamatan yang diinputkan

Combobox 2 : Tombol untuk memilih nama juru parkir yang diinputkan.

\subsection{Rancangan Form Menu Cetak Data Juru Parkir}

Tampilan ini berfungsi sebagai tempat untuk mencetak data juru parkir. Seperti gambar 4.11

DATA JURU PARKIR

Pilih Kecamatan
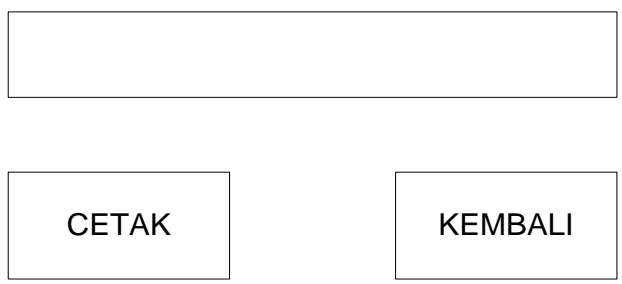

Gambar 4.11 Rancangan Form Cetak Data Juru Parkir

Keterangan :

Cetak : Tombol untuk mencetak laporan

Kembali : tombol untuk kembali dari halaman cetak.

\subsection{Rancangan Form Menu Cetak Data Transaksi}

Tampilan ini berfungsi sebagai tempat untuk mencetak data transaksi. Gambar 4.12

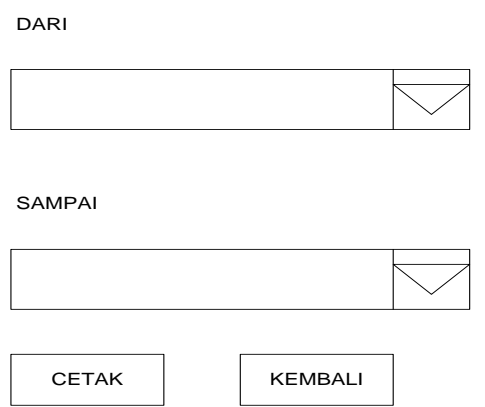

Gambar 4.12 Form Cetak Data Transaksi Keteragan :

Cetak : Tombol untuk mencetak laporan

Kembali : tombol untuk kembali dari halaman cetak.

\subsection{Rancangan Form Cetak ID Card}

Tampilan ini berfunsi sebagai tempat untuk mencetak tanda pengenal pada juru parkir. Gambar 4.13

ID CARD

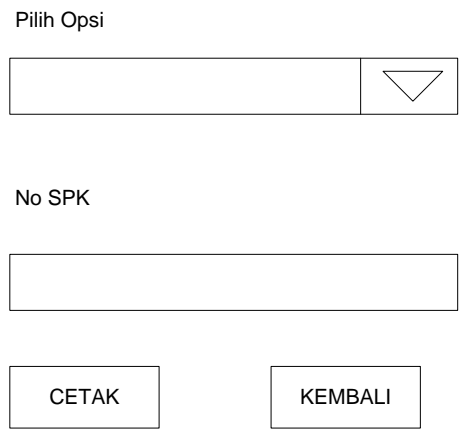

Gambar 4.13 Rancangan Cetak ID Card Keterangan :

Cetak : Tombol untuk mencetak laporan

Kembali : tombol untuk kembali dari halaman cetak.

\subsection{Rancangan Form Laporan Data Juru Parkir}

Tampilan ini berfungsi sebagai hasil laporan dari data juru parkir bertugas. Gambar 4.14

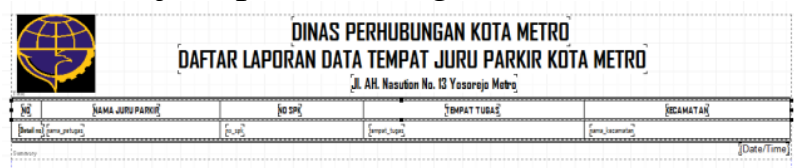


Gambar 4.14 Rancangan Form Laporan Data Juru Parkir

Keterangan :

No

: Berisi nomor urutan

Nama Juru Parkir : Berisi nama dari masing-masing juru parkir

Tempat Tugas : Berisi lokasi parkir dari masing-masing juru parkir

Kecamatan : Berisi kecamatan dari setiap lokasi parkir.

\subsection{Rancangan Form Laporan Data Setoran beserta Tempat Tugas}

Tampilan ini berfungsi sebagai hasil laporan dari setoran beserta tempat tugas setiap juru parkir. Gambar 4.15

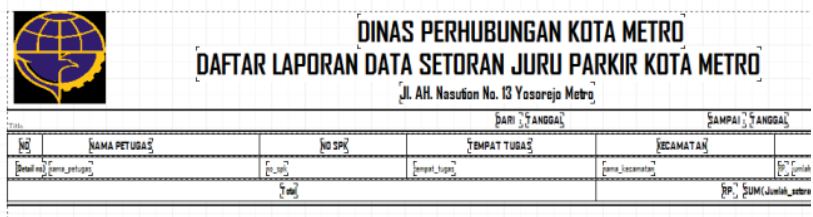

Gambar 4.15 Rancangan Form Laporan Data Setoran beserta Tempat Tugas

Keterangan :

No $\quad$ : Berisi nomor urutan

Nama Juru Parkir : Berisi nama dari masing-masing juru parkir

Tempat Tugas : Berisi lokasi parkir dari masing-masing juru parkir

Kecamatan : Berisi kecamatan dari setiap lokasi parkir.

Setoran : Berisi jumlah setoran dari setiap juru parkir.

\subsection{Rancangan Form Laporan Kartu Tanda Pengenal Juru Parkir}

Tampilan ini berfungsi sebagai hasil cetak dari ID CARD. Gambar 4.16
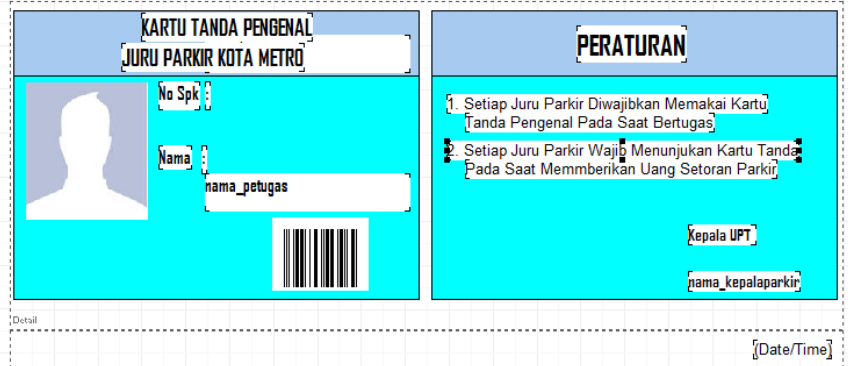

Gambar 4.16 Rancangan Form Kartu Tanda Pengenal

Keterangan

No SPK : Berisikan nomor spk dari setiap juru parkir

Nama : Berisikan nama dari setiap juru parkir.

\subsection{Pembahasan Program}

\section{Tampilan Halaman Menu Login}

Tampilan login berfungsi untuk membuka atau masuk ke menu utama dengan user dan password yang benar. Adapun form login dapat dilihat pada Gambar 4.17

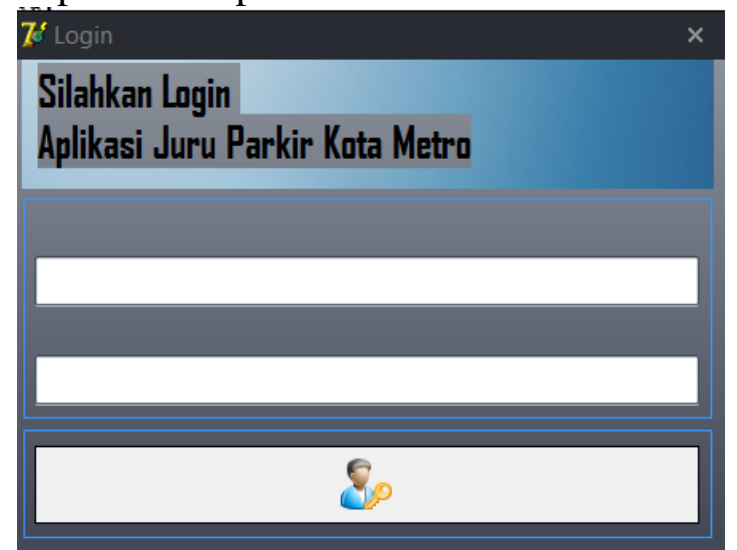

Gambar 4.17 Tampilan Login Pada Program Keterangan :

Username : Berisikan nama pengguna

dari pengguna

Password : Berisikan password

Masuk : Tombol untuk

masuk ke sistem

\subsection{Tampilan Halaman Menu Utama}

Tampilan ini berfungsi sebagai tempat untuk menampilkan form-form data juru parkir dan 
laporan. Adapun rancangan form dapat dilihat pada gambar 4.18

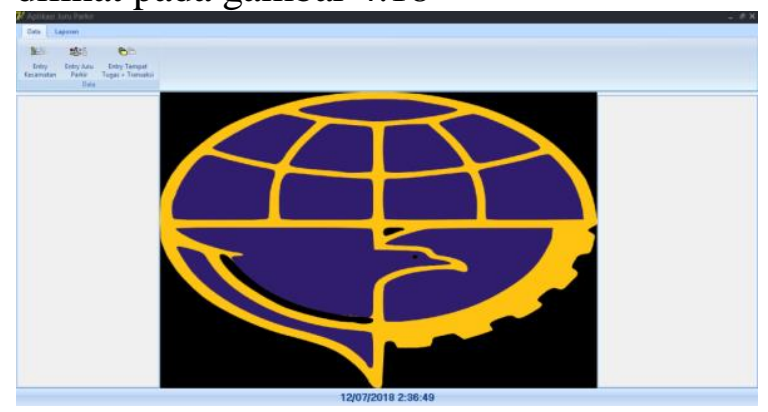

Gambar 4.18 Tampilan Menu Utama Pada Program

Keterangan :

Data : Berisikan Data dari juru parkir, tempat tugas dan setoran

Laporan : Berisikan laporan-laporan yang untuk dicetak

Logo : Berisikan identitas dari instansi tersebut.

\subsection{Tampilan Input Data Kecamatan Pada Aplikasi}

Tampilan ini berfungsi untuk mengetahui dimana letak kecamatan pada tempat tugas dari juru parkir. Gambar 4.19

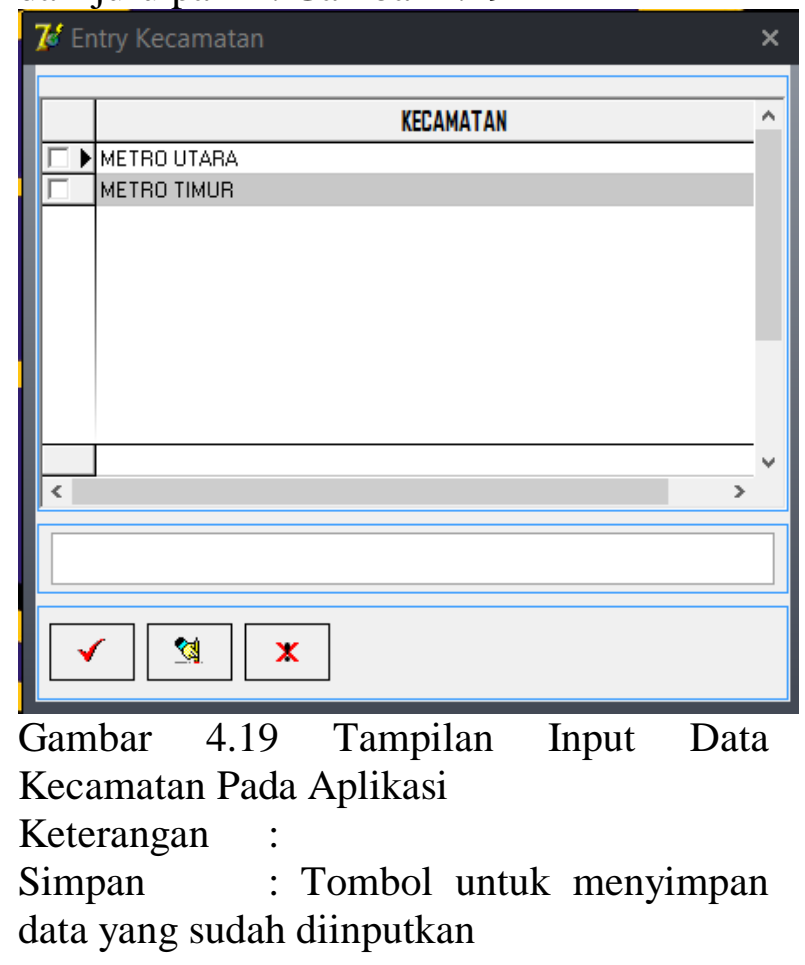

Edit

: Tombol untuk merubah data yang sudah disimpan Hapus : Tombol untuk menghapus data yang ada.

\subsection{Tampilan Input Data Juru Parkir}

Tampilan ini berfungsi sebagai tempat untuk memasukkan data juru parkir. Gambar 4.20

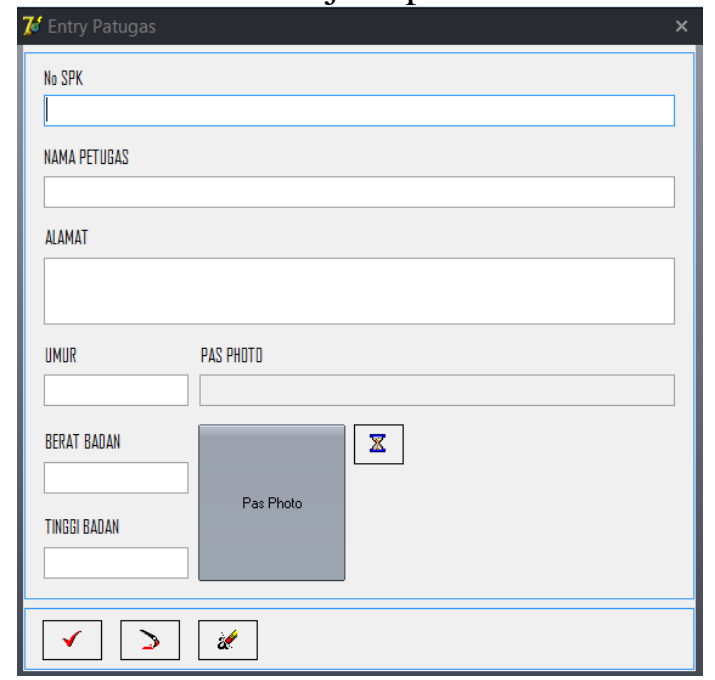

Gambar 4.20 Tampilan Menu Input Data Juru Parkir

Keterangan :

Simpan : Tombol untuk menyimpan data yang sudah diinputkan

Edit : Tombol untuk merubah data yang sudah disimpan

Hapus : Tombol untuk menghapus data yang ada.

\subsection{Tampilan Menu Input Data Tempat Tugas Juru Parkir}

Tampilan ini berfungsi sebagai tempat menginputkan data tempat tugas pada setiap juru parkir. Gambar 4.21 


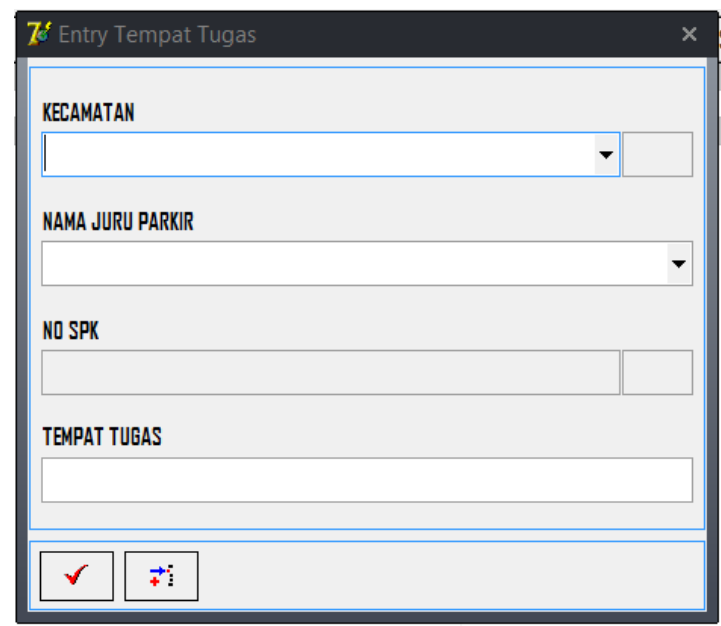

Gambar 4.21 Tampilan Menu Input Tempat Tugas

Keterangan :

Simpan : Tombol untuk menyimpan data yang sudah diinputkan

Hapus : Tombol untuk menghapus data yang ada.

Combobox 1 : Tombol untuk memilih kecamatan yang diinputkan

Combobox 2 : Tombol untuk memilih nama juru parkir yang diinputkan.

\subsection{Tampilan Menu Input Setoran}

Tampilan ini berfungsi sebagai tempat transaksi juru parkir dalam menyerahkan setoran kepada petugas. Gambar 4.21

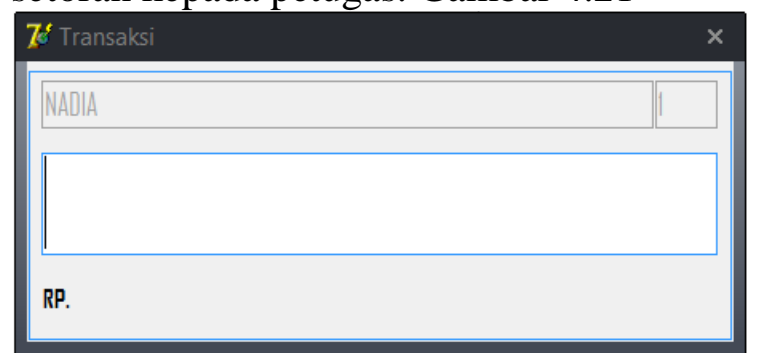

Gambar 4.21 Tampilan Menu Input Setoran Keterangan :

TextEdit 1 : $\quad$ Berfungsi untuk menampilkan nama juru parkir

TextEdit 2 : $\quad$ Berfungsi untuk menampilkan id juru parkir TextEdit 3 : Berfungsi untuk memasukkan jumlah setoran.

\subsection{Tampilan Menu Cetak Data Petugas Parkir}

Tampilan ini berfungsi sebagai tempat untuk mencetak data juru parkir. Seperti gambar 4.22

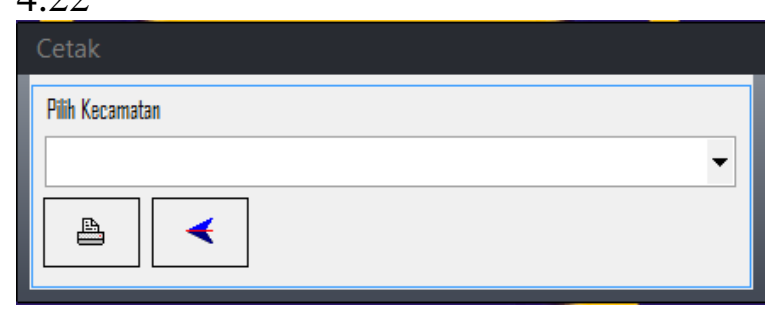

Gambar 4.22

Keterangan :

Cetak : Tombol untuk mencetak laporan

Kembali : tombol untuk kembali dari halaman cetak.

\subsection{Tampilan Menu Cetak Data Transaksi dan Tempat Tugas}

Tampilan ini berfungsi sebagai tempat untuk mencetak data transaksi beserta tempat tugas. Gambar 4.23

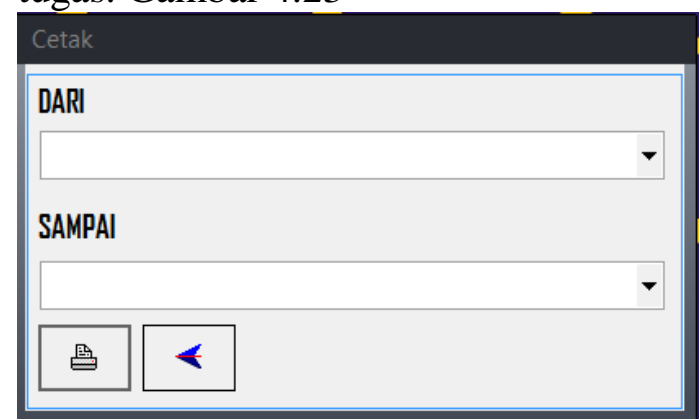

Gambar 4.23 Tampilan Menu Cetak Data Transaksi

Keterangan :

Cetak : Tombol untuk mencetak laporan

Kembali : tombol untuk kembali dari halaman cetak.

\subsection{Tampilan Menu Cetak Kartu Tanda Pengenal}

Tampilan ini berfungsi sebagai tempat untuk mencetak kartu tanda pengenal juru parkir. Gambar 4.24 


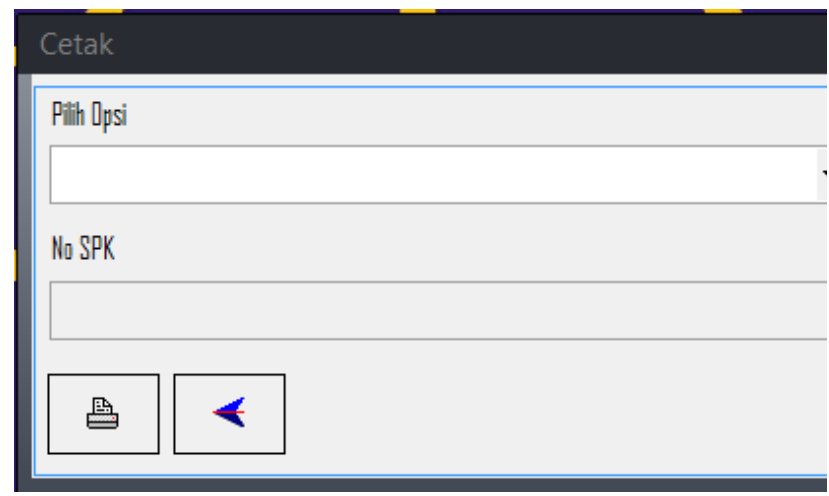

Gambar 4.24

Keterangan :

Cetak : Tombol untuk mencetak laporan

Kembali : tombol untuk kembali dari halaman cetak.

\subsection{Tampilan Laporan Data Juru Parkir}

Berisikan hasil laporan dari data juru parkir. Gambar 4.25

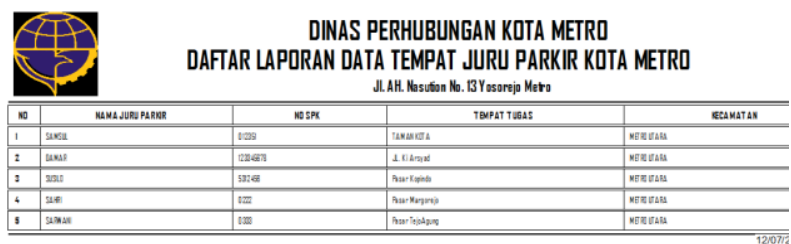

Gambar 4.25 Tampilan Laporan Data Juru Parkir

Keterangan :

No

: Berisi nomor urutan

Nama Juru Parkir : Berisi nama dari masing-masing juru parkir

Tempat Tugas : Berisi lokasi parkir dari masing-masing juru parkir

Kecamatan : Berisi kecamatan dari setiap lokasi parkir.

\subsection{Tampilan Laporan Data Setoran beserta Tempat Tugas}

Tampilan ini berfungsi sebagai hasil laporan dari setoran beserta tempat tugas setiap juru parkir. Gambar 4.26

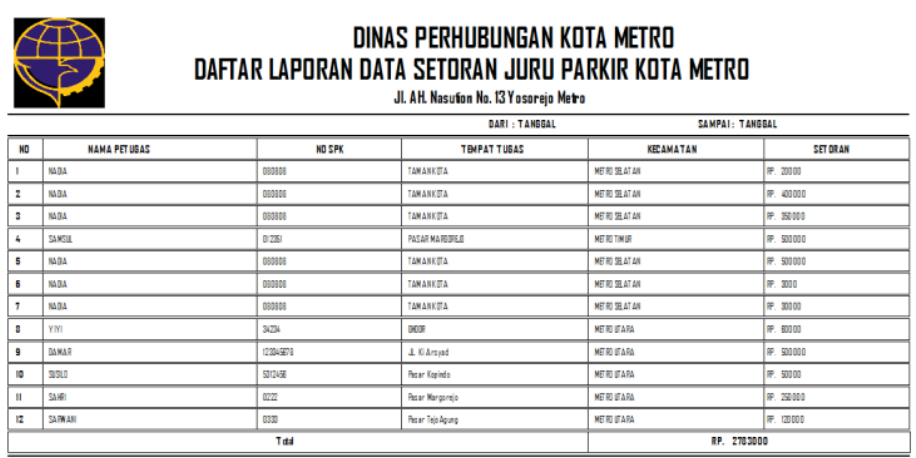

Gambar 4.26 Tampilan Laporan Data Setoran Beserta Tempat Tugas

Keterangan :

No $\quad$ : Berisi nomor urutan

Nama Juru Parkir : Berisi nama dari masing-masing juru parkir

Tempat Tugas : Berisi lokasi parkir dari masing-masing juru parkir

Kecamatan : Berisi kecamatan dari setiap lokasi parkir.

Setoran : Berisi jumlah setoran dari setiap juru parkir.

\subsection{Tampilan Kartu Tanda Pengenal Juru Parkir}

Tampilan ini berfungsi sebagai identitas dari juru parkir. Gambar 4.27
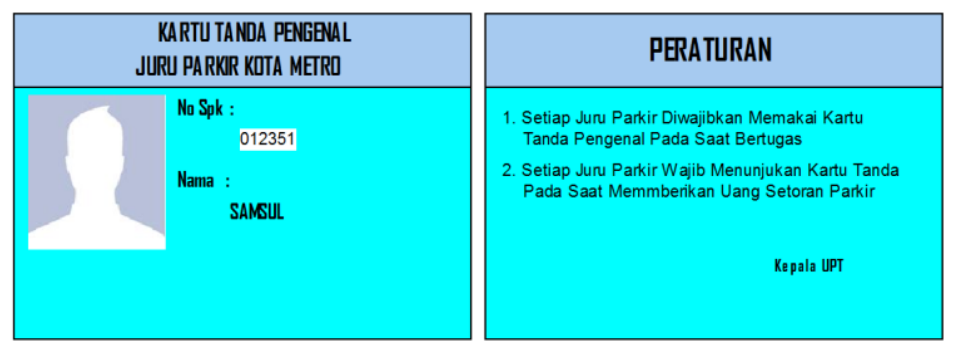

Gambar 4.27 Kartu Tanda Pengenal Juru Parkir

Keterangan :

No SPK : Berisikan nomor spk dari setiap juru parkir

Nama : Berisikan nama dari setiap juru parkir

\subsection{Kelebihan dan Kelemahan Sistem}




\section{Kelebihan Sistem}

Mempermudah dalam proses pengolahan data karyawan Waktu efisien dalam pembuatan laporan Mempermudah operator dalam proses input, edit dan pencarian maupun penyimpanan data karyawan.

\section{Kelemahan Sistem}

Adapun kelemahan dari aplikasi ini belum dapat diakses secara online Tampilan desain pada aplikasi program ini masih sederhana Aplikasi masih perlu pengembangan kreasi sesuai dengan pengembangan Prasarana Aplikasi Teknologi ini masih dekstop.

\section{KESIMPULAN}

Untuk pengembangan lebih lanjut penulis memberikan saran yang sangat bermanfaat dan dapat membantu proses pengolahan data karyawan pada Dinas Perhubungan Kota Metro untuk masa yang akan datang yaitu :

1. Dalam pembuatan aplikasi ini, penulis berharap agar aplikasi ini dapat dikembangkan menjadi lebih baik kedepannya dan penulis membuat aplikasi ini sesuai dengan pengamatan yang dilakukan pada Dinas Perhubungan Kota Metro.

2. Sebaiknya untuk kedepannya sistem ini dibuat laporan untuk setiap juru parkir yang ada.

3. Perawatan terhadap sistem perlu diperhatikan agar sistm ini dapat beroperasi secara maksimal.

4. Jika dalam pembuatan aplikasi ini terdapat suatu kekurangan, khususnya dalam hal desain antar muka penulis berharap untuk pengembangan lebih lanjut dapat ditingkatkan.

5. Sebaiknya untuk bagian Kasubbag Umum khususnya operator dapat diikutsertakan dalam pelatihan-pelatihan secara continue agar dapat mengikuti perkembangan kemajuan di bidang IT.

\section{DAFTAR PUSTAKA}

[1] Agus Prayitno dan Yulia Safitri. 2015. Pemanfaatan Sistem Informasi Perpustakaan Digital Berbasis Website Untuk Para Penulis. Indonesian Journal On Software Engineering. Vol.1 No.1. ISSN : 2461-0690.

[2] Dahria. 2011. Metode Akses Data ODBC dan OLE DB. Jurnal SAINTIKOM. Vol 10 No. 1

[3] H.M, Jogiyanto. 1999. Pengenalan Komputer. Yogyakarta: ANDI Yogyakarta.

[4] H.M, Jogiyanto. 2005. Analisis \& Desain. Yogyakarta: Andi Offset.

[5] Irnawan. 2006. Memahami Pemrograman Delphi 7. Jakarta: BSI PRESS. Kadir, Abdul. 2009. Dasar Perancangan \& Implementasi. Yogyakarta: ANDI Yogyakarta. Komputer, Wahana. 2015. Membangun Sistem Informasi dengan Java NetBeans dan MySQL. Yogyakarta: CV. ANDI.

[6] Ladjamudin, Al Bahra Bin. 2005. Analisis \& Desain Sistem Informasi. Yogyakarta: Graha Ilmu.

Melfa, Bella, Chintya dan Tamara, Dony. 2016. Perancangan Aplikasi E-Canteen Berbasis Android Dengan Menggunakan Metode Object Oriented Analysis \& Design $(O O A D)$. Jurnal Penelitian Komunikasi dan Opini Publik 20 (2016): 83-91.

[7] Mujiati, Hanik dan Sukadi. 2011. Analisis dan Perancangan Sistem Informasi Stok Obat pada Apotek Arjowinangun. Indonesian Jurnal on Computer Science. ISSN : 2088-0154.

Purba. 2016. Rancang Bangun Pengolahan Data Penggajian Pada Lembaga Akuntansi Manajemen Informatika (LAMI) Komputer. Jurnal Informatika. Vol.2 No. 2. ISSN : 2407-1730. 
Sembiring, Hermasnyah (dkk). 2012. Sistem Informasi Jumlah Angkatan Kerja Menggunakan Visual Basic Pada Badan Busat Statistik (BPS) Kabupaten Langkat. Jurnal KAPUTAMA. Vol.5 No.2. ISSN : 1979-6641.

[8] Simarmata, Janner, dan Paryudi, Janner. 2010. Basis Data. Yogyakarta: ANDI Yogyakarta Sofyan, Asep, Abdul. (dkk). 2016. Perancangan Aplikasi Sistem Pakar Deteksi Dini Kerusakan Mobil Toyota Avanza. Jurnal SIFOTEK GLOBAL. Vol.5 No.1. ISSN : 2088-1762

[9] Supriyanta dan Nisa. 2015. Perancangan Website Desa Wisata Karangrejo Sebagai Media Informasi Dan Promosi. Jurnal Bianglala Informatika. Vol. 3 No.1. ISSN : 2338-9761 